Southern Methodist University

SMU Scholar

Faculty Journal Articles and Book Chapters

Faculty Scholarship

2017

\title{
With Jurors in Mind: An Ethnographic Study of Prosecutors' Narratives
}

Anna Offit

Southern Methodist University, Dedman School of Law

\section{Recommended Citation}

Anna Offit, With Jurors in Mind: An Ethnographic Study of Prosecutors' Narratives, Law, Culture and the Humanities Journal (2017)

This document is brought to you for free and open access by the Faculty Scholarship at SMU Scholar. It has been accepted for inclusion in Faculty Journal Articles and Book Chapters by an authorized administrator of SMU Scholar. For more information, please visit http://digitalrepository.smu.edu. 
With jurors in mind:

An ethnographic study of prosecutors' narratives

\author{
Anna Offit*
}

Contact information:

315 East $65^{\text {th }}$ Street, Apt. 6J

New York, NY 10065

(917)-359-8206

annaoffit@gmail.com 


\begin{abstract}
This article examines the role of lay decision-makers in American prosecutors' case preparation. Drawing on ethnographic research, it focuses on the creative and collaborative process by which prosecutors develop and revise opening and closing statements for trial. I argue in Part I that these narratives are keyed to perspectives that prosecutors attribute to hypothetical jurors. Part II focuses on the relationship prosecutors articulate between particular narrative techniques and jurors' perceptions of their character and evidence. The central empirical finding is that prosecutors formulate and negotiate narratives about their cases with continual reference to jurors' potential interpretations of them. This interactional process of critique and revision reveals the contingent and reflexive nature of prosecutorial discretion. It also offers a window into the social knowledge that prosecutors draw on to anticipate how jurors might scrutinize their work.
\end{abstract}

\title{
Keywords
}

Legal profession, prosecutors, narrative, lay participation, legal technique, prosecutorial discretion, ethics 


\section{Acknowledgments}

*PhD Candidate, Princeton University; JD, Georgetown University Law Center; MPhil, University of Cambridge. I am profoundly indebted to the 133 anonymous Assistant United States Attorneys who made this study, and the larger project of which it is a part, possible. I am also grateful to Carol Greenhouse, Lawrence Rosen, Peter Brooks, Kim Lane Scheppele, Richard A. Wilson, Kelly McKowen, Matthew Birkhold, Sveinung Sandberg, Robin West, Gregory Klass, Michael Frisch, David Luban, Louis Michael Seidman, the University of Oslo Narrative Criminology Working Group, and the Georgetown University Law Center Fellows Seminar. Thank you, also, to a peer reviewer for sustained and supportive engagement with this article. This research was supported in part by the National Science Foundation. 
American prosecutors' opening and closing statements are often concise, polished, and recited from memory by the time jurors hear them. Ethnographic research in federal prosecutors' offices, however, reveals that the process of creating such narratives is far from neat. They are often written in fits and starts: drafts are emailed, printed, returned with suggested changes, revised, re-circulated and critiqued aloud during meetings with colleagues. This was true, for example, of an opening statement that a prosecutor named Mark prepared for United States v. Caprica, a mortgage fraud case. Hunched over a pile of notes in a windowless conference room, he glanced up from scattered pages on the table in front of him. His audience of prosecutors, meanwhile, looked past him at an image projected on a retractable screen. It was an aerial photograph of a destroyed building. ${ }^{1}$

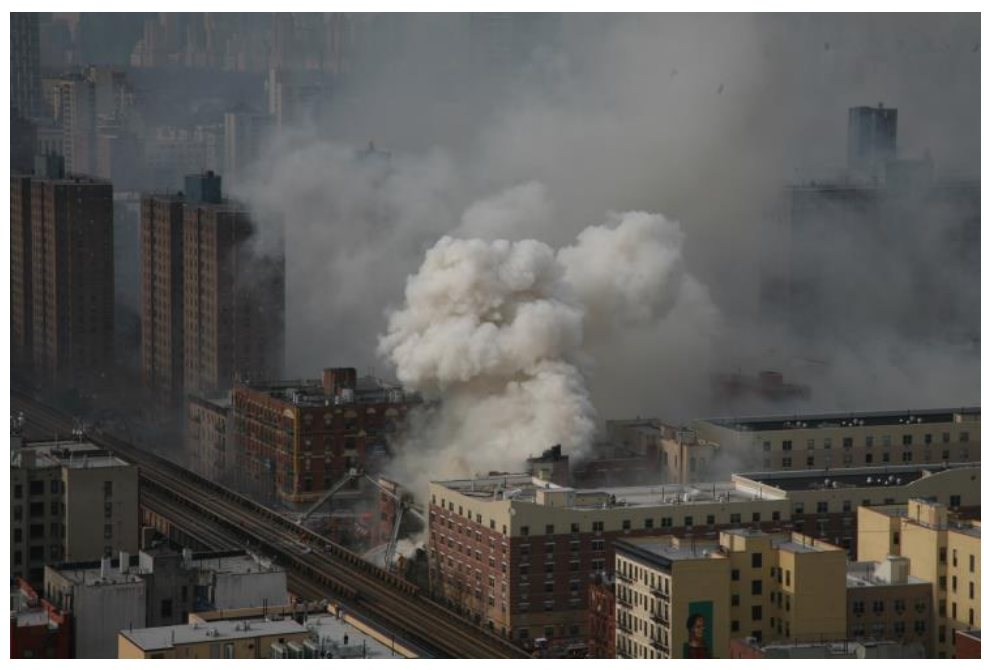

\footnotetext{
${ }^{1}$ This photograph of a similar gas explosion was taken by Adnan Islam and is available here: https://www.flickr.com/photos/adnanbangladesh/13107208504/ under a Creative Commons license.
} 
Mark's colleagues set cell phone timers and peeled their legal notepads to fresh pages. The story began:

It was two o'clock in the afternoon when 2850 Beach Street exploded. It was a gas explosion. The building was leveled by a powerful, violent blast. One woman died and five others were critically injured. It shook the entire block. Homes all the way down the street had their windows blown out and building number 2850 no longer existed. The defendant knew about the explosion, and that this property ceased to exist. It was all over the local news all day. But the evidence will show that the defendant stood to gain hundreds of thousands of dollars by pretending the building was still there.

The defendant, the theory went, saw the explosion as an opportunity. Posing as a loan officer, he could pocket money for the building's fictitious sale. He did this by submitting fraudulent mortgage loan applications to banks on behalf of straw buyers. For each loan obtained through this scheme, the defendant took a commission for himself.

Beginning the story with a pile of rubble and casualties, however, was a novel narrative flourish. Though the image appeared on screen only briefly, it remained on Mark's colleagues' minds as they responded with suggestions:

- It's confusing. When you're sitting there, you think it's a case about arson, or national security, or weapons of mass destruction... 
- It's a powerful picture. It has shock value... it's a question of when you want to deploy it.

- Let's go back to the vignette. How do we shorten the vignette? I'm reading it [in reference to a printed draft of the opening] and I'm just not sure how to shorten it. $^{2}$

These reactions highlight several issues that are central to this article. First, they illuminate the collaborative process by which lawyers negotiate and re-make narratives about their cases. They also reveal prosecutors' attention to the perspectives of future listeners. This particular case, like most in the office, did not proceed to trial. Nevertheless, prosecutors oriented their preparation around perspectives that they imputed to hypothetical jurors.

This study draws on long-term participatory research in three United States Attorney's offices in a federal district in the Northeast United States. ${ }^{3}$ In 2010 I served as a legal intern in the largest of these offices before returning to carry out anthropological research between 2013 and 2017. This included interviews with 133 Criminal and Civil Division prosecutors and participation in 68 case preparation meetings. It also involved participant observation, which entailed the long-term study of prosecutors' everyday work by contributing to it. ${ }^{4}$ This sustained and immersive approach, which is characteristic of ethnographic research, was facilitated by my training as a lawyer and

\footnotetext{
${ }^{2}$ Participation in meeting, U.S. Att'y's Office, (Jan. 28, 2014).

${ }^{3}$ The general location of these offices is identified for the benefit of researchers who wish to extend this case study to other parts of the country to examine regional differences among U.S. Attorney's offices.

${ }^{4}$ See e.g., Annelise Collateral Knowledge: Legal Reasoning in the Global Financial Markets. (Chicago, Chicago University Press 2011), p. 11 for discussion (and use) of a similar ethnographic approach.
} 
admission to the bar in states that included the site of this fieldwork. To preserve the anonymity of all prosecutors and cases, I have changed or coded their names.

Though it is beyond the scope of this analysis, my broader argument is that prosecutors negotiate and formulate the meaning of their professional imperative to seek justice with reference to real and imagined jurors. ${ }^{5}$ I contend that prosecutors draw on jurors' hypothetical perspectives to bring clarity to their ideas about just prosecutions and the values that support them. ${ }^{6}$ This article, more specifically, addresses jurors' influence on prosecutors' organization of their legal expertise and other forms of knowledge as narratives. This included prosecutors' local knowledge about ordinary peoples' lives as well as their intuitions about how these citizens might assess their credibility. After briefly situating the study of legal narratives-in-progress in the context of emergent interdisciplinary research, Part I examines the extent to which opening and closing statement preparation was oriented toward future jurors' hypothetical perspectives. Part II focuses on the relationship prosecutors articulated between particular narrative techniques and jurors' anticipated perceptions of their character and evidence. As prosecutors discussed the stakes of proposed revisions, they gave explicit and implicit definition to the limits of their discretion.

\footnotetext{
${ }^{5}$ Am. Bar Ass'n, ABA Standards for Criminal Justice: \$3-1.2(b) "The primary duty of the prosecutor is to seek justice within the bounds of the law, not merely to convict"; Berger v. United States" 1934 p. 88 ; "The United States Attorney is the representative not of an ordinary party to a controversy, but of a sovereignty whose obligation to govern impartially is as compelling as its obligation to govern at all; and whose interest, therefore, in a criminal prosecution is not that it shall win a case, but that justice shall be done."; 63C Am. Jur. 2d 2013.

6 This finding complements anthropologists' observation that identity formation is an interactive and "contextually situated" process that emerges through real time discourse See e.g., Matoesian, Gregory M. Law and the Language of Identity: Discourse in the William Kennedy Smith Rape Trial. (Oxford; New York, Oxford University Press 2001), p. 166; Keane, Webb. Ethical Life: Its Natural and Social Histories, (Princeton: Princeton University Press 2015), p. 78; Bashkow, Ira. The Meaning of Whitemen (Chicago, University of Chicago Press 2006), p. 20.
} 


\section{Narrative-creation as an object of ethnography}

Analyses of legal narratives can conceal the inherently contingent, collaborative, and improvisational character of legal practice. ${ }^{7}$ This is because much scholarship focuses on outcomes (e.g., verdicts, judicial opinions) and adopts backward-looking reasoning from already settled ends. ${ }^{8}$ Clifford Geertz describes this analytic tendency as a “"how-to' bias" that treats the effects of legal practice as constitutive of law more generally. ${ }^{9}$ Emergent interdisciplinary studies of legal narratives, however, increasingly capture their dynamic and contingent character, shaped by rules and principles that legal actors deploy differently. ${ }^{10}$ For anthropologists and scholars in adjacent fields, these insights stem from an understanding of legal practice as dialogic, interactive, and collaborative. ${ }^{11}$ Through this lens, even in-court statements begin to look like products of

\footnotetext{
${ }^{7}$ Cormack, Bradin. Power to Do Justice : Jurisdiction, English Literature, and the Rise of Common Law 1509-1625 (Chicago, University of Chicago Press 2008), p. 1; Shapiro, Martin “On the Regrettable Decline of Law French: Or Shapiro Jettet Le Brickbat." Yale Law Journal, January 1980, p. 1201; Sarat, Austin, and Felstiner, William L. F. "Lawyers and Legal Consciousness: Law Talk in the Divorce Lawyer's Office.” The Yale Law Journal 98 (8) 1989., p. 1682; Coutin, Susan Bibler. Legalizing Moves : Salvadoran Immigrants' Struggle for U.S. Residency (Ann Arbor University of Michigan Press 2000), p. 122; see also Scheppele, Kim Lane "Facing Facts in Legal Interpretation." Representations, no. 30 April 1990, p. 60. ${ }^{8}$ Roland Barthes helpfully characterizes this process as one of "retrospective prophes[y]" Barthes, Roland. A Barthes Reader. (New York 2009). p. 225; see also Ginzburg, Carlo. Clues, Myths, and the Historical Method. (Johns Hopkins University Press 1992).

${ }^{9}$ Geertz, Clifford. Local Knowledge: Further Essays in Interpretive Anthropology. (New York, Basic Books 2000), p. 233; Pirie, Fernanda. The Anthropology of Law (Oxford 2013), pp. 67-68 suggesting that anthropologists have a tendency to examine "what law does" rather than what law is; Foucault, Michel. The Order of Things: An Archaeology of Human Sciences (Random House 2012), p. 267.

${ }^{10}$ Wilson, Richard Ashby. Writing History in International Criminal Trials (Cambridge University Press 2011), p. 109; Yngvesson, Barbara. Virtuous Citizens, Disruptive Subjects: Order and Complaint in a New England Court. (Routledge 1993), p. 45 referring to law as a variously deployed "resource" in local power struggles; Greenhouse, Carol and Kheshti, Roshanak. Democracy and Ethnography: Constructing Identities in Multicultural Liberal States (SUNY Press 1998), p. 15.

${ }^{11}$ See e.g., Riessman, Catherine Kohler in Inhorn, Marcia C. and van Balen, Frank (eds.) Infertility around the Globe: New Thinking on Childlessness, Gender, and Reproductive Technologies. (University of California Press 2002); Brookman, Fiona in Presser, Lois, and Sveinung Sandberg, eds. Narrative Criminology: Understanding Stories of Crime. (New York Univ Press 2015), p. 3; Yngvesson supra note 12, pp. 228-230; Hill, Jane H. Responsibility and Evidence in Oral Discourse (Cambridge University Press 1993), p. 1, 4; Bauman, Richard "Verbal Art as Performance" American Anthropologist 77 (2) 1975, p. 302; Bakhtin, Mikhail Mikhaĭlovich, Wright, Jay and Holquist, Michael. The Dialogic Imagination: Four
} 
co-narration in which multiple narratives fuse to produce a "public story."12

Likewise, legal language has been studied as a medium for different possible outcomes, drawing on a repertoire of discursive strategies. ${ }^{13}$ Divorce lawyers' speech offers a compelling example, revealing how invocations of formalist, equitable, and realistic conceptions of law inform the interpretive frames that such attorneys selectively present to their clients. ${ }^{14}$ And some scholars set aside consideration of legal outcomes altogether, focusing instead on the uncertainty of verdicts. ${ }^{15}$

Unlike analyses that treat lawyers' trial narratives as static objects of analysis, the creation of such stories is a significant context for ethnographic study in its own right. One prosecutor analogized his focus on jurors' perceptions of opening statements to his process of evaluating FBI agents' case pitches early in an investigation. "It's almost like the script is flipped," he explained:

I'm now the jury and the agent is trying to convince me it's something worth doing

Essays (University of Texas Press 1981), pp. 293-294; Jacoby, Sally, and Ochs, Elinor. "Co-Construction: An Introduction" Research on Language \& Social Interaction 28 (3) 1995, p. 175; Duranti, Alessandro "The Audience as Co-Author: An Introduction" Text - Interdisciplinary Journal for the Study of Discourse 6 (3) 1986, p. 241; Goffman, Erving. The Presentation of Self in Everyday Life (New York [N.Y.]: Doubleday 1990); Hall, Stuart. Representation : Cultural Representations and Signifying Practices (London; Thousand Oaks, Calif: Sage in association with the Open University 1997), p. 235 noting that meaning is generated through interaction with an "Other."

${ }^{12}$ Richland, Justin B. Arguing with Tradition: The Language of Law in Hopi Tribal Court (Chicago: University of Chicago Press 2008), pp. 118-119; 1997; Ochs, Elinor, and Lisa Capps. Living Narrative: Creating Lives in Everyday Storytelling (Harvard University Press, 2009), pp. 57-58, 95, 242; Sarat, Austin, and Felstiner, William L. F. Divorce Lawyers and Their Clients: Power and Meaning in the Legal Process (Oxford University Press 1997), pp. 17-18; Bauman in Silverstein, Michael, and Urban, Greg Urban (eds). Natural Histories of Discourse (Chicago: University of Chicago Press 1996).

${ }^{13}$ See e.g., Sarat, Austin, and Felstiner, William L. F. in Levi, Judith N., and Anne Graffam Walker (eds.) Language in the Judicial Process (Springer 1990), p. 136.

${ }^{14}$ See Sarat and Felstiner supra note 9; see also Hirsch, Susan F. Pronouncing and Persevering: Gender and the Discourses of Disputing in an African Islamic Court (University of Chicago Press 1998); Ng, Kwai Hang. The Common Law in Two Voices: Language, Law, and the Postcolonial Dilemma in Hong Kong (Stanford University Press 2009).

${ }^{15}$ Amsterdam, Anthony G., and Randy Hertz "Analysis of Closing Arguments to a Jury," New York Law School Law Review, 37 (1992), p. 56 analyzing the language used during closing statements in a 1991 homicide prosecution in New York which emphasizes the uncertainty of legal outcomes. 
and the same process is taking place. I may not consciously be thinking to myself "what will a jury think of this" but what I am saying to myself is "is this the kind of thing we should be concerned about?" When you put yourself in this position, you're put in the position of a jury thinking, "what kind of appeal is this going to have?"16

The sections that follow demonstrate that prosecutors' critiques of colleagues' trial narratives are rooted in the similar imaginative exercise of anticipating jurors' reactions to them.

\section{Jurors at the center of opening and closing statements}

Jurors' potential interpretations of evidence were at the heart of prosecutors' discussions of case narratives. Although accessing jurors' impressions was an inherently speculative endeavor, ${ }^{17}$ prosecutors nonetheless developed robust beliefs about their future lay decision-makers. ${ }^{18}$ In some cases, prosecutors explicitly identified "average" jurors as individuals who were middle-class, employed, and lived in the suburbs. ${ }^{19}$ In other cases, prosecutors' understandings of jurors stemmed from knowledge of family

\footnotetext{
${ }^{16}$ Interview with CZ, Ass't U.S. Att'y, (July 15, 2013), his emphasis.

${ }^{17} \mathrm{Cf}$., Participation in meeting with CZ during which a prosecutor said he learned jurors' first-hand impressions from a post-trial meeting that was permitted in another jurisdiction where he worked as an Assistant District Attorney (May 5, 2017); see also Discussion with BG, Ass't U.S. Att'y, (May 23, 2017) during which a juror who served as an alternate in a case wrote a letter to the judge before the defendant was sentenced.

${ }^{18}$ See e.g., Zalman, Marvin and Tsoudis, Olga, "Plucking Weeds From the Garden: Lawyers Speak About Voir Dire," 51 Wayne L. Rev. 1632005.

${ }^{19}$ Offit, Anna "Peer Review: Navigating Uncertainty in the United States Jury System", UC Irvine Law Review Vol. 6, Issue 2, June 2016. p. 180, by one prosecutor's account, average jurors "“go to work every day, have 2.5 kids, drive a Ford Taurus, and have a white picket fence."
} 
members or friends who shared characteristics in common with them (e.g., occupations, counties of residence) and were thus regarded as proxy jurors. ${ }^{20}$

When it came time to prepare opening and closing statements, the distinction between prosecutors' interpretive capacities and those of the jurors they imagined was ambiguous at best. Lawyers, in other words, became surrogate jurors for each other. For some, the aim of preparation meetings was to discuss and refine language that might resonate with laypeople. For others, presentation style was a narrative priority, as prosecutors likened themselves to teachers. In both cases, jurors' perspectives were invoked and imaginatively enacted by prosecutors as part of a practice of distancing themselves from cases to offer critiques from a position of detachment.

1. Crafting language with jurors in mind

Several prosecutors emphasized the importance of using analogies in opening statements that jurors might relate to. This included a lawyer who kept a list of details about jurors in front of her during opening statements and throughout trials. "If I have carpenters or teachers on my jury," she explained,

I will try to phrase arguments to connect personally with them. If I am talking about money laundering or a narcotics trafficking organization utilizing a black market exchange I might focus jury addresses on something like "the tools of the trade of a narcotics officer..." or "just like a carpenter has a hammer, nails,

\footnotetext{
${ }^{20}$ Id. pp. 198-199; See e.g., Participation in meeting with EM, Ass't U.S. Att'y, (May 5, 2017) during which a prosecutor acknowledged that jurors' reactions to a bank robbery surveillance video might mirror those of her trial partner.
} 
pens..." to engage them individually. "Just like a nurse has medicine..." you address jurors keeping in mind all the time what their individual lives are like. ${ }^{21}$

While preparing for a trial two years later, the same prosecutor said that she could tell when jurors were receptive to her metaphors by observing their "eyes light up" as she connected with them as individuals. ${ }^{22}$ Even if jurors did not find such references persuasive, another prosecutor explained, they might at least pay attention. ${ }^{23}$ When another prosecutor noted that several members of a jury were parents she made a conscious effort to use analogies involving children, likening the use of circumstantial evidence, for instance, to concluding that a child had eaten cookies after noticing crumbs on his face, chocolate on his breath, and an empty, open cookie jar beside him in the kitchen. ${ }^{24}$

In the similar spirit of keying language used in opening and closing statements to jurors' likely experiences outside the courtroom, another prosecutor weighed presentation styles that future listeners might be receptive to. "If you have a teacher or an auto mechanic," he explained,

it is going to affect your argument in different ways. If you have a teacher, you want to be the outstanding student with answers to every question. If you have an engineer you want to give facts, weights, and percentages. If it's a hockey player

\footnotetext{
${ }^{21}$ Interview with DN, Ass't U.S. Att'y, ( July 18, 2013).

${ }^{22}$ Interview with DN, Ass't U.S. Att'y, (Aug. 12, 2015); see also Interview with CH, Ass't U.S. Att'y, (Jul. 8, 2013) commenting "I like to think of a jury as $m y$ jury and I like to relate to them. I like to know who they are." Her emphasis.

${ }^{23}$ Interview with BT, Ass't U.S. Att'y, (Jun. 28, 2013).

${ }^{24}$ Participation in meeting with AY and BQ, Ass't U.S. Att'ys, (Aug. 13, 2013).
} 
you might use more aggressive language. You want to know that so you can craft the message. You don't move the facts around, but you adjust the presentation. ${ }^{25}$

Consideration of jurors' divergent backgrounds thus prompted creative discussion of how cases might appear to unfamiliar observers. Recognizing that people rely on analogies to reconcile informational gaps in everyday life, ${ }^{26}$ prosecutors eagerly reframed evidence to align with knowledge systems that might bring clarity to sources of confusion in court.

In other cases, efforts to engage jurors were more explicitly aimed at advancing particular interpretations of significant evidence. In a civil suit, for example, a prosecutor tasked with defending the United States made a point of referring to a record of communications between an air traffic controller and pilot as a partial transcript rather than a transcript. This "definition" - as he referred to it — was significant because it underscored the incompleteness of the interactions the jury learned about in court; the air traffic controller was responsible for up to eight airplanes at a time. The plaintiff, in contrast, referred to an edited version of the transcript that made it appear as though the airplane at issue was the sole focus of the employee's attention. ${ }^{27}$ Despite the infrequency of jury trials in civil cases, this prosecutor recognized the stakes of neglecting jurors' potential adoption of the language used throughout a trial. Here, as part of his strategy, the prosecutor implicitly highlighted an aspect of the story that jurors were not privy to.

Other prosecutors mined jurors' responses to voir dire questions for clues about how to characterize evidence that might strike a layperson as counterintuitive. To

\footnotetext{
${ }^{25}$ Interview with BJ, Ass't U.S. Att'y, (June 26, 2013).

${ }^{26}$ Rosen, Lawrence. Law as Culture: An Invitation (Princeton University Press, 2006), p. 9; Lakoff, George, and Mark Johnson. Metaphors We Live By. (University of Chicago Press, 1980), p. 119; Douglas, Mary. How Institutions Think. (Syracuse University Press., 1986), p. 65.

${ }^{27}$ Interview with BY, Ass't U.S. Att'y, ( July 2, 2013).
} 
disabuse jurors of the notion that fingerprints and DNA evidence were essential components of criminal investigations, for example, a prosecutor revisited her notes on jurors' television habits. If many of them reported watching crime shows like "CSI", she incorporated this fact into her opening statements. Unlike popular legal dramas, she then explained, jurors would learn from experts that DNA rarely solved cases in real life. By commenting on jurors' exposure to fictionalized law enforcement work, she hoped to manage their expectations and anticipate questions that might arise during their deliberations. ${ }^{28}$ In the context of a child abuse case, a different prosecutor prepared for a closing statement by revisiting the voir dire responses of jurors who believed that children could love parents who abused them. In his view, invoking jurors' understandings of the complexity of abusive relationships might bolster his own common sense argument that the defendants' intermittent expressions of warmth and affection did not mitigate their guilt. ${ }^{29}$

In an effort to use language that might resonate with jurors, prosecutors recognized the importance of drawing on local knowledge when formulating their arguments. Some accessed this knowledge by drawing on vocabulary from divergent professional registers (e.g., analogies tailored to carpenters, nurses, or athletes) or from opinions elicited during voir dire (e.g., related to DNA evidence and abuse). Consideration of jurors' perspectives thus blurred lay and professional expertise — both of which permeated prosecutors' talk and decision-making.

\footnotetext{
${ }^{28}$ Interview with BU, Ass't U.S. Att'y, (July 1, 2013); Participation in meeting with AW, Ass't U.S. Att'y, (May 4, 2017) during which a supervisor encouraged the deliverer of an opening statement to emphasize details about DNA evidence in a bank robbery case because they affirmed public confidence in law enforcement's technological capabilities.

${ }^{29}$ Interview with BQ, Ass't U.S. Att'y, (June 28, 2015).
} 
2. Making evidence intelligible to lay decision-makers

Opening statements, which could range from 10 minutes to several hours, were selective by necessity; they sounded more like previews than fulsome stories. ${ }^{30}$ For the prosecutors who practiced, critiqued, and ultimately delivered them, this was by design. These statements were intended to offer jurors a "broad brush", "bare bones" understanding of the charges and evidence in cases and to pare down complex or unpredictable testimony into simple narratives. ${ }^{31}$ A benefit of this approach, as prosecutors saw it, was the possibility that concise narratives would be more compelling and memorable than detailed or long-winded ones. To refine their stories, prosecutors critiqued each other's presentations from the vantage point of hypothetical lay decisionmakers. This meant that suggestions for revision could be articulated in impersonal terms as prosecutors scrutinized evidence with fresh eyes. It also assumed that prosecutors' concerns could be substituted in conversation for those of future jurors. ${ }^{32}$

Nevertheless, thus aided by colleagues, many prosecutors viewed their task in crafting opening statements as one of making the facts of a case and elements of a crime intelligible to an imagined lay audience. ${ }^{33}$ As part of this effort, which some viewed as central to their job, prosecutors encouraged each other to transform evidence into "sound bites of key information" 34 , "simple thought[s]" 35 , or language that a juror "could

\footnotetext{
${ }^{30}$ In advance of trial, judges sometimes encouraged parties to adhere to time limits for their opening statements to keep the proceedings on schedule; see also Observation of trial proceedings (Sept. 19, 2016). ${ }^{31}$ See e.g., Participation in meetings, U.S. Att'y's Office, (April 19, 2017; June 7, 2013).

${ }^{32}$ Cf. Participation in meeting, U.S. Att'y's Office, (May 4, 2017) during which a colleague cautioned a trial team that "weak" characterizations of evidence in an opening revealed their "own subjective anxiety about the case" rather than evince confidence that jurors would find the evidence "devastating."

${ }^{33}$ Participation in meetings, U.S. Att'y's Office, (June 7, 2013; Sept. 3, 2013; Jan. 8 2015).

${ }^{34}$ Participation in meeting, U.S. Att'y's Office, (June 7, 2013).

35 Participation in meetings, U.S. Att'y's Office, (July 1, 2014; April 19, 2017).
} 
reasonably digest." ${ }^{36}$ As one prosecutor explained, "the more you can define factual issues to the jury and define the facts of the case they're going to have to decide, the easier it will be for them and the easier it will be for you." ${ }^{37}$ Another prosecutor referred to his professional obligation to translate legal language for laypeople as a "burden of coherence." Viewing this responsibility as a narrative burden, he added that

to the extent there are gaps and there are holes in what we can explain or in what we can make comprehensible to the jury, that's to our detriment. Anything - if you're missing a shoe, to analogize it, that's to my detriment... Anything that is out of kilter contributes to doubt. ${ }^{38}$

Others conceptualized the task of teaching jurors about their cases as part of their duty to "close logical loops" ${ }^{39}$, "connect the dots", ${ }^{40}$ "marry up" different aspects of a crime, ${ }^{41}$ and "lay out" why particular pieces of evidence were significant. ${ }^{42}$ Exemplifying this approach, a supervisor suggested that paragraphs of an opening statement in a bribery case be revised to sound like a primer for jurors. ${ }^{43}$ Here, again, the imagined perspectives of individuals who lacked professional training helped prosecutors assess evidence in their cases anew.

\footnotetext{
${ }^{36}$ Participation in meeting, U.S. Att'y's Office, (June 9, 2013); see also Discussion with DN and DH, Ass't U.S. Att'ys, (May 23, 2017).

${ }^{37}$ Participation in meeting, U.S. Att'y's Office, (June 19, 2013); see also participation in meeting with CZ, Ass't U.S. Att'y, (April 25, 2017).

${ }^{38}$ Interview with BE, Ass't U.S. Att'y, (June 21, 2013).

${ }^{39}$ Participation in meetings, U.S. Att'y's Office, (Oct. 9, 2014; Jan. 8, 2015).

${ }^{40}$ Participation in meeting, U.S. Att'y's Office, (Oct. 17, 2016).

${ }^{41}$ Participation in meeting, U.S. Att'y's Office, (Jan. 28, 2015).

${ }^{42}$ Participation in meetings, U.S. Att'y's Office, (June 7, 2013; Oct. 22, 2016).

${ }^{43}$ Participation in meeting, U.S. Att'y's Office, (Feb. 21, 2017).
} 
To aid jurors' comprehension of cases, "colloquial," "conversational," "down to earth," "plain" and "everyday" language was prized; prosecutors sought to craft stories in terms used and heard outside of court. ${ }^{44}$ During preparation meetings for fraud, drug, and gun cases, for example, prosecutors' critiques of opening statements distinguished between the level of precision and detail one might expect from a written brief and oral story. In a brief, a prosecutor explained, it might be appropriate to list the monetary values of dozens of loans or note the number of days between transactions. In the context of an oral opening statement, however, quantitative description did little to contribute to jurors' understanding. ${ }^{45}$ In this prosecutor's view, an opening suffered for being "too wordy, too legalese, and too complex." 46 A similar argument surfaced in a gun possession case in which a prosecutor was told: "This sounds as if you wrote it as opposed to 'let me tell you what happened...' like you're just talking to the jury. If you were just telling them what happened, you'd use different words. It would sound different from the way it would if it was a scholarly lecture." 47

For some, this approach presumed that jurors who failed to understand evidence, or got lost in its detail, might mistake their confusion for defects in a case. ${ }^{48}$ This was

\footnotetext{
${ }^{44}$ See e.g., Interview with BS, Ass't U.S. Att'y, (Dec. 1, 2015); Interview with DK, Ass't U.S. Att'y, (Dec. 1, 2015); Interview with AA, Ass't U.S. Att'y, (July 8, 2013); Interview with DA, Ass't U.S. Att'y, (Feb. 6 , 2015) commenting on the importance of using "vocabulary that would resonate" with jurors; Interview with AA, Ass't U.S. Att'y, (Feb. 6, 2015); Interview with AB, Ass't U.S. Att'y, U.S. Att'y's Office, (Feb. 6, 2015); Interview with CH, Ass't U.S. Att'y, (July 8, 2013) "Tell them a story they can understand and get them to believe in you, because you believe in what you're saying"; Participation in meetings, U.S. Att'y's Office, (Jan. 8, 2015; March 4, 2015).

${ }^{45}$ See also Participation in meeting with AA, Ass't U.S. Att'y, (May 4, 2017) during which a prosecutor discouraged the deliverer of an opening statement from emphasizing quantitative DNA test results in favor of colloquial phrasing.

${ }^{46}$ Participation in meetings, U.S. Att'y's Office, (Jan. 8, 2015; Feb. 21, 2017; April 19, 2017).

${ }^{47}$ Participation in meeting, U.S. Att'y's Office, (April 3, 2014), his emphasis; see also Participation in meeting with BS, Ass't U.S. Att'y (Dec. 1, 2015) noting that an opening statement in a drug case sounded like a "beautifully written brief" rather than a story.

${ }^{48}$ Interview with AZ, Ass't U.S. Att'y, ( June 21, 2013); Interview with AW, Ass't U.S. Att'y, (June 20, 2013); Interview with BD, Ass't U.S. Att'y, (June 21, 2013; Oct. 19, 2014).
} 
true, for example of prosecutors who tried RICO (Racketeer Influenced and Corrupt Organizations Act) cases and worried that if jurors heard a story involving numerous defendants their confusion might lead to acquittals. ${ }^{49}$ To this end, one prosecutor critiqued a colleague's presentation for portraying his case as too "nuanced and detailed" and not straightforward enough. 50

A case that involved the theft and shipment of cars prompted a similar response from a colleague who thought that

the details in the beginning really jump out but I think the opening is too detailed. This is a simple case. Name the steps. Step one: the car is stolen. Step two: you let the car cool off by leaving it on the street. Step three: you clean the car. Then you warehouse it and change the VIN number. After the warehouse you put the car in [a] crate. It's a process with five basic steps for how to steal a car. ${ }^{51}$

Earlier in the discussion, a different colleague commented that the jury, like him, might be confused by the fact that homeland security officers had authorized the stolen car's shipment as part of their investigation. There was consensus that this detail did not "make the cut" for the opening; its deliverer was persuaded that it would raise more questions for jurors than it would answer and "ultimately, you want the jury to understand." 52 Prosecutors sometimes elaborated aspects of cases that could not easily be distilled into simple stories, pointing out that defendants made sophisticated efforts to conceal their

\footnotetext{
${ }^{49}$ Interview with BV, Ass't U.S. Att'y, (July 1, 2013).

${ }^{50}$ Participation in meeting, U.S. Att'y's Office, (June 7, 2013).

${ }^{51}$ Participation in meeting, U.S. Att'y's Office, (June 7, 2013).

${ }^{52}$ Id.
} 
wrongdoing. For example, one prosecutor explained that a fraud case took him hours to understand: "I put up a slide that looks incredibly complicated and I say 'look at this. The defendant made this complicated so that he wouldn't be here today.' So I embrace the complexity." 53

In the cases outlined above, references to jurors' fictive perspectives informed prosecutors' critiques of colleagues' language use. In the process, prosecutors sometimes clarified aspects of cases for themselves. A 10-minute opening statement for a child pornography case, for example, prompted discussion of substantive legal questions. "You described child pornography as child sexual abuse," a colleague commented after a runthrough. "Isn't that just a subset of child pornography?" 54 In the discussion that followed prosecutors fluidly tacked back and forth between their need to refine legal characterizations of sexually explicit images for lay listeners and for each other. Requests for a "better road map," topic sentences, and colloquial definitions highlighted the jury's role as an editorial resource and context in which legal knowledge was tested and exchanged. ${ }^{55}$

\section{Formulating justice while forming a story}

In his essay The Narrative Construction of Reality, Jerome Bruner highlights the interplay between narrative form and normative commitments. Citing Frank Kermode, he

\footnotetext{
${ }^{53}$ Interview with BJ, Ass't U.S. Att'y, (June 26, 2013), his emphasis.

${ }^{54}$ Participation in meeting with FI, Ass't U.S. Att'y, (April 25, 2017).

${ }^{55}$ Id.; see also Polanyi, Livia. Telling the American Story: A Structural and Cultural Analysis of Conversational Storytelling (Cambridge, Massachusetts, The MIT Press). 1989. p. 93 for a relevant discussion of "interactively constructed" meaning in conversational storytelling.
} 
underscores the role that narratives play in rendering the world orderly and intelligible. ${ }^{56}$ In a similar fashion, prosecutors' collaborative construction of opening and closing statements imposed order on ambiguities in their cases and professional commitments. As prosecutors critiqued colleagues' case characterizations they explicitly and implicitly distinguished narrative approaches that embodied personal and professional character traits they viewed as essential to their work. As this section demonstrates, prosecutors' self-consciousness about their perceived reliability and fairness featured prominently in their discussions.

1. The prosecutor as credible author

Prosecutors recognized the role that opening and closing statements played in building and maintaining jurors' trust. ${ }^{57}$ In practice, however, they took divergent approaches to demonstrating their credibility and articulated distinct professional values in the process. This included ensuring that opening statement narratives aligned with evidence jurors would see or hear during trial, conveying their preparedness, assuming responsibility for educating jurors about federal law, and foregrounding corroborating evidence.

During discussions of opening statements, in particular, prosecutors spent time

\footnotetext{
${ }^{56}$ Bruner, Jerome. "The Narrative Construction of Reality" Critical Inquiry 18 (1) 1991; Kermode, Frank. The Sense of an Ending; Studies in the Theory of Fiction (Oxford University Press 1967); see also Mitchell, W. J. Thomas. On Narrative (University of Chicago Press 1981); Lévi-Strauss, Claude. The Structural Study of Myth (University of Pennsylvania 1955); Mattingly, Cherly and Garro, Linda C. eds. Narrative and the Cultural Construction of Illness and Healing. (University of California Press, Berkeley 2000), pp. 11-25.

${ }^{57}$ See e.g., Discussion with HD and DN, Ass't U.S. Att'ys (May 23, 2017).
} 
scrutinizing the specificity and accuracy of their characterizations of evidence. ${ }^{58}$ Underlying this effort was an assumption that a juror whose expectations were betrayed by later inconsistencies would call a prosecutor's character - and therefore argumentsinto question. The stories prosecutors fashioned for jurors were thus regarded as "commitments" or promises to them. ${ }^{59}$ Violations of this trust were referred to as problems of "overcommitting", "overselling," or "overpromising" in opening statements. ${ }^{60}$ The excerpt below illustrates the conversational process by which prosecutors shared and critiqued the narratives they expected witness testimony to later support. The defendants in the case were charged with using a firearm to steal a car:

Vaughn: Ok. So you don't know who was standing on what side of the car or who said "get the fuck out of the car"? Be slow and deliberate: "The victims saw a shotgun and heard the words 'get the fuck out of the car' and, ladies and gentlemen, this is the shotgun they saw." Have the victims seen the gun?

Stacy: They say... the defendant was wearing a long — a trench coat and that he held the gun in front of him upright — in the middle. The female says she doesn't really know guns but she says her husband does and that it's not a handgun. That it's long and black...

Vaughn: Ok. They say black?

\footnotetext{
${ }^{58}$ See e.g., Participation in meeting, U.S. Att'y's Office, (Jan. 8, 2015).

${ }^{59}$ Participation in meeting with AA, Ass't U.S. Att'y, (April 17, 2014).

${ }^{60}$ See e.g., Participation in meeting with ED, Ass't U.S. Att'y, (Feb. 21, 2017); Participation in meeting with AD, Ass't U.S. Att'y, (June 19, 2013); Participation in meeting with AJ, Ass't U.S. Att'y, (May 4, 2017); Participation in meetings, U.S. Att'y's Office, (April 19, 2017; Oct. 9, 2014; Jan. 8, 2015).
} 
Stacy: Yeah.

\section{Vaughn: Ok.}

Jeff: You don't want [defense counsel] holding the gun up and saying "have you seen this before?" and the victim saying, "I don’t think so. I don't really know."

Vaughn: Definitely prepare them for that ${ }^{61}$

Anticipating that jurors might not hear evidence clarifying who held the gun, a supervisor and colleague suggested that the deliverer of the opening statement highlight the insignificance of the detail she could not commit to. "The defendant is criminally responsible for using a gun in furtherance of a carjacking...," the supervisor said, rehearsing a proposed revision of the narrative aloud. "The evidence will show that even if Chris didn't tell you that Brent, himself, carried the gun, Chris and Brent are both criminally responsible."62 A colleague added that a succinct way to help the jury "pull all the evidence together" was to note that the defendant "acted consistently with someone who knew the gun was there." 63

Where prosecutors positively reinforced precise language, ${ }^{64}$ vagueness was a source of disagreement. ${ }^{65}$ This is because the extent of a particular word or phrase's

\footnotetext{
${ }^{61}$ Participation in meeting, U.S. Att'y's Office, (July 1, 2014).

${ }^{62} \mathrm{Id}$.

${ }^{63} I d$., his emphasis.

${ }^{64}$ Participation in meeting with DA, Ass't U.S. Att'y, (Feb. 6, 2015).
} 
ambiguity was negotiable. In one case, a prosecutor's appeal to "common sense" was perceived as signaling that the trial team's evidence was insufficient, requiring that jurors make an excessive inferential leap to convict a defendant. ${ }^{66}$ Common sense, in this lawyer's view, was too indeterminate and subjective a metric for lay decision-makers. In another case, a prosecutor criticized a colleague's suggestion that jurors might "hear things" during the trial that departed from his opening statement. Though the trial team wanted to anticipate contrary arguments from defense counsel, a colleague warned them that such vagueness might lead jurors to believe they would hear something harmful to the government's case. ${ }^{67}$ "It implies this case is so nuanced that if you don't get all of the details, you can't convict," he continued. "But that's not the case at all." 68

At the same time that prosecutors considered the risk of later contradiction (or benefit of later corroboration) they did not want to be perceived as withholding evidence that did not support their cases. They referred to the practice of sharing ambiguous or unfavorable information during opening statements as "fronting" evidence. ${ }^{69}$ An aim of this technique was to demonstrate their candor to jurors. ${ }^{70}$ When a prosecutor was not certain how defense counsel would use evidence that a defendant only offered commissions on some of the bribes he solicited, for example, a supervisor encouraged him to bring this detail out in his opening lest jurors think to themselves, "they never told

\footnotetext{
${ }^{65}$ Participation in meeting with EJ, Ass't U.S. Att'y, (Feb. 6, 2015) urging a colleague to avoid "wishy washy adjectives like "somewhat" or refer to "some" of the defendants' conduct as illegal.

${ }^{66}$ Participation in meeting, U.S. Att'y's Office, (Sept. 3, 2013); see also participation in meeting with BB (Jun. 21, 2013); Participation in meeting, U.S. Att'y's Office, (July 1, 2014).

${ }^{67}$ Participation in meeting with AG, Ass't U.S. Att'y, (Jun. 7, 2013).

${ }^{68} I d$., his emphasis.

${ }^{69}$ See e.g., Participation in meetings, U.S. Att'y's Office, (Feb. 21, 2017; May 4, 2017).

${ }^{70}$ Meeting with DN, Ass't U.S. Att'y, (July 17, 2015) during which prosecutor explained that "Out of 47 trials I've never lost one. I know I'm good at what I do and know how to differentiate myself from my opponents by showing I'm trustworthy, believable, likable, and have good evidence"; see also Participation in meeting, U.S. Att'y's Office, (Oct. 9, 2014).
} 
us that!"71 In a healthcare fraud case that unfolded over a 14-month period and consisted of two illegal transactions, a colleague worried that representing the crime as taking place over "more than a year" and involving "more than one transaction" could lead jurors to expect evidence of a larger scheme. In a similar vein, a prosecutor warned a colleague in a different case not to "overplay or underplay" the extent to which a defendant tried to run away from two police officers by "twisting" his body, since neither officer described the maneuver clearly and later contradiction could affect the jury's assessment of the trial team and witnesses' truthfulness. ${ }^{72}$

Prosecutors' commitment to maintaining jurors' trust led some to make a concerted effort to communicate in an informal, relatable, and conversational manner. ${ }^{73}$ In one such case, a prosecutor's effective connection with her listeners during a preparation meeting was lauded as the culmination of continued practice. ${ }^{74}$ The absence of such a connection was considered a shortcoming in other prosecutors' presentations. ${ }^{75}$ The stakes of establishing a rapport with jurors, in some prosecutors' view, were high. One prosecutor thought that if he seemed like someone a juror would want to "hang out" with, that person might be more likely to listen to and trust him. ${ }^{76}$ Other prosecutors were attuned to whether they (or their trial partners) had "some kind of simpatico" or felt a personal connection with a particular juror during voir dire. ${ }^{77}$

\footnotetext{
${ }^{71}$ Participation in meeting with AA, Ass't U.S. Att'y, (Feb. 21, 2017).

72 Participation in meeting, U.S. Att'y's Office, (April 3, 2014).

${ }^{73}$ Participation in meeting with AA, Ass't U.S. Att'y, (Feb. 6, 2015); Participation in meeting with FA (Feb. 21, 2017).

${ }^{74}$ Participation in meeting, U.S. Att'y's Office, (June 7, 2013).

75 See e.g., Participation in meeting, U.S. Att'y's Office, (June 19, 2013) during which a prosecutor advised his colleague to "connect with the jury for a few minutes" rather than begin an opening statement with a slideshow.

${ }^{76}$ Interview with BT, Ass't U.S. Att'y, (June 28, 2013).

77 See e.g., Interview with BD, Ass't U.S. Att'y, (June 20, 2013); Discussion with DN, Ass't U.S. Att'y, (May 23, 2017).
} 
Many prosecutors felt that demonstrations of their preparedness by memorizing details in their cases signaled to jurors that they took their jobs and audience seriously. ${ }^{78}$ In a gun possession case, for example, a prosecutor emphasized the importance of confidently describing the weapon's name, model, size, and place of origin. 'I've done a lot of gun cases," she explained, "and I like to know that gun. I hold it up and say 'this is a BLANK', without looking down, because that goes to my credibility. I know this gun. This is my case. You're going to have it in your hand and look right at them as you say it." 79 Echoing this sentiment, another prosecutor agreed that references to minutia show you know what's going to happen- you're in command of this case. Like, "I know all the facts and I'm going to tell you, some of these witnesses are going to be a little problematic, and here's why: The stuff they did was illegal." So to me it just shows you have control of the case. ${ }^{80}$

Detailed references, these prosecutors agreed, might enhance their credibility by exhibiting their own factual proficiency. Correspondingly, in light of the value conferred on precision, prosecutors' misstatements of evidence- or displays of inconsistent facts on PowerPoint slides — were sharply criticized because of their anticipated impact on jurors. ${ }^{81}$

\footnotetext{
${ }^{78}$ Interview with DD, Ass't U.S. Att'y, (July 16, 2013); Interview with AE, Ass't U.S. Att'y, (June 11, 2013); Participation in meeting, U.S. Att'y’s Office, (June 19, 2013).

${ }^{79}$ Participation in meeting with EF, Ass't U.S. Att'y, (April 3, 2014), her emphasis.

${ }^{80}$ Participation in meeting with BT, Ass't U.S. Att'y, (Feb. 6, 2015).

${ }^{81}$ See e.g., Participation in meeting, U.S. Att'y's Office, (Jan. 8, 2015); see also Participation in meeting with EI and AJ, Ass't U.S. Att'ys (May 5, 2017).
} 
Prosecutors were also conscious that the language they used could affect perceptions of the criminality of defendants' conduct. To this end, prosecutors tried to underscore the illegitimate and illegal dimensions of defendants' behavior. Comments from a meeting in preparation for a car theft trial exemplified this approach. Here, a prosecutor pointed out that

when you use words like "contracts" and "employees" it makes it seem like a legitimate business. You may want to do a little up front on the legitimate aspect of the business but say that we're talking about the illegitimate thing. This will give context. So throw it up front and introduce the concept. ${ }^{82}$

Another colleague offered advice along similar lines, suggesting the lead prosecutor "explain all the things she did in her illegal enterprise to steal cars." ${ }^{3}$ Rather than use words and phrases like "businesswoman," "business associate," "partner," and "profit for her business," he recommended language that drew attention to the defendant's wrongdoing — such as "co-conspirator" and "illegal enterprise."84

A political corruption case raised similar concerns for a prosecutor who observed:

I don't think I heard the word kickback once. It was like, "he made a recommendation and he got a share.” That sounded pretty legitimate to me. I

\footnotetext{
82 Participation in meeting, U.S. Att'y’s Office, (June 7, 2013).

${ }^{83}$ Participation in meeting, U.S. Att'y's Office, (June 7, 2013), his emphasis.

${ }^{84}$ Participation in meetings, U.S. Att'y's Office, (June 7, 2013; Jan. 7 2014; Jan. 8, 2014; July 1, 2014); Participation in meeting, U.S. Att'y's Office, (Oct. 18, 2016) during which a prosecutor encouraged a colleague to "channel a little more skepticism" in his descriptions; Participation in meeting with AW, Ass't U.S. Att'y, (May 4, 2017) during which a colleague advised a trial team to describe the defendant as stealing rather than taking money from a bank.
} 
would say, instead of "he helped get them hired, he got a piece of the action", "he helped get them hired, he got a kickback." It's a kickback case and I don't think we say kickback. ${ }^{85}$

A colleague who participated in this meeting suggested the opening statement be revised to sound "bribyer." Despite the narrative's strong delivery, "at the end of the day... it's just a matter of tightening it up and bribing it up a little more, frauding it up, and extorting it up a little."86 These comments echoed others in criminal cases in which colleagues recommended identifying "the defendant" (rather than "he" or "she"), referring to cooperators as "co-conspirators" 87 and using words like "hitting" instead of "discipline" 88 which reinforced the illegality of the conduct they described. Prosecutors also recommended characterizing defendants' actions in active voice when possible: "he told her he hid the files", for example, rather than "he told her the files were locked up."89

Underlying some prosecutors' careful attention to word choice was broader concern that jurors might fail to view a defendant — or his conduct — as criminal. Their narrative work thus embraced an obligation to accurately characterize, explain, and communicate the significance of the laws at issue in their cases. Discussion of a convicted felon charged with carrying a firearm was instructive in this regard:

\footnotetext{
${ }^{85}$ Participation in meeting, U.S. Att'y's Office, (Feb. 6, 2015).

${ }^{86}$ Participation in meeting, U.S. Att'y's Office, (Feb. 6, 2015).

${ }^{87}$ Participation in meeting, U.S. Att'y's Office, (June 7, 2015).

${ }^{88}$ Participation in meeting, U.S. Att'y's Office, (Oct. 9, 2014).

${ }^{89}$ Participation in meeting with AJ, Ass't U.S. Att'y, (Feb. 21, 2017).
} 
Luis: You started [the opening] with the law — and I wouldn't. I always start with a grabber fact - and I'm not a big fan of starting with the law. You could say, "the defendant had just committed a traffic infraction" with just two or three sentences of description — just hitting them with a fact. Something brief. Like "they were on patrol in a high crime area and saw someone speeding. But what happened next was quite unusual..."

Ava: Is it? I wouldn't say it's quite unusual...

Ken: I disagree...

Ava: Otherwise, people will be thinking, "why is the U.S. government caring? This is just a gun case." So the federal part is important — because why are we here on a gun case? Why is the government wasting its time and resources...

Ken: ....it's illegal under federal law...

Luis: You've got to get into the cadence — looking at the jury — and just grabbing them... "What happened next was quite unusual. And why?"

Ken: But a lot of people don't know carrying a gun is a crime. Usually I'd agree with you, but not here. It's a matter of style, there's no right way to do it... 
Luis: See, I disagree. It just doesn't grab you...

Lena [the author of the draft statement]: I read four opening transcripts for gun possession cases and they all started with the law....90

One can quickly appreciate the group's attentiveness to the question of whether an opening should begin with a hook meant to grab and engage listeners, or outline the law a defendant was charged with breaking. ${ }^{91}$ The stakes of this decision for some of the prosecutors who discussed it, however, were higher. What if jurors saw nothing wrong with the defendant's conduct? Both Ken and Ava emphasized the possibility that for a layperson unfamiliar with laws restricting felons' right to possess guns, a narrative that failed to flag this fact might confuse jurors - or worse - make them question the prosecutors' judgment. Ideas about narrative sequence were thus tied to prosecutors' conceptions of their professional roles. Accepting the risk of boring jurors, Ken believed that the trial team's obligation to assert the legitimacy of a case should trump concern about how to order the events in their story.

Prosecutors also sought to demonstrate their credibility by inviting jurors to carry out narrative work of their own. This entailed presenting themselves as neutral purveyors of independent and mutually reinforcing evidence of wrongdoing. As a practical matter, this also meant emphasizing that distinct pieces of evidence could lead one to the same conclusion about a defendant's guilt. Jurors could interpret complementary, overlapping,

\footnotetext{
${ }^{90}$ Participation in meeting, U.S. Att'y's Office, (April 17, 2014).

${ }^{91}$ See e.g., Participation in meeting, U.S. Att'y's Office, (Oct. 9, 2014); Participation in meeting with BS, Ass't U.S. Att'y, (Dec. 1, 2015) encouraging the inclusion of a "punchy first sentence" that would tell a story "up front."
} 
or "lined up" accounts of a defendant's actions, in other words, as evidence of their facticity. ${ }^{92}$ This approach was distinguished from presentations that appeared to rely on discrete pieces of evidence (e.g., surveillance footage, DNA evidence, eyewitness testimony) as though each existed in a vacuum. The skillful closing statement or rebuttal, in contrast, directed jurors" attention to "all those things taken together."93

The narrative significance of corroborating evidence emerged with particular force during a child abuse prosecution. To support her theory of the defendants' medical neglect of their children, the case's lead prosecutor planned to show the jury medical records that documented doctors' referrals to seek immediate follow-up treatment and the defendants' subsequent failure to follow through. She would then show the jury records generated by administrators listing numerous appointments the defendants had cancelled or missed. During a commute home, the prosecutor described her assembly of multiple narratives of neglect as "leaving no stone unturned," allowing the jury to "cross-check" her claims. ${ }^{94}$ This prosecutor, like others, underscored the value of offering several accounts of the same conduct to reinforce her own credibility in the event that jurors chose not to believe a particular witness. ${ }^{95}$ In closing statements and rebuttals, prosecutors sometimes stressed the fact that their cases relied on distinct but complementary pieces of evidence to anticipate or address defense counsel's arguments. This was a move that explicitly placed interpretive and inferential work in jurors' hands. ${ }^{96}$ If jurors connected the dots themselves, prosecutors might emerge as neutral and

\footnotetext{
${ }^{92}$ See e.g., Participation in meeting with AZ, Ass't U.S. Att'y, (June 20, 2013).

${ }^{93}$ See e.g., Participation in meeting with CZ, Ass't U.S. Att'y, (May 5, 2017), his emphasis.

${ }^{94}$ Discussion with AY, Ass't U.S. Att'y, (March 26, 2015).

${ }^{95} \mathrm{Id}$.

${ }^{96}$ See e.g., Participation in meeting with AA, Ass't U.S. Att'y, (May 4, 2017) during which a prosecutor encouraged the deliverer of an opening statement to find the defendant guilty on the strength of their own identification of him using video surveillance footage and contemporaneous photographs.
} 
therefore more reliable curators of their evidence.

A human trafficking prosecution illustrated this approach further. In this case, a victim named Jessica testified that she was locked in a basement and forced to have sex with strangers. When questioned by defense counsel, however, her description of this experience did not match the prosecutors' opening statement. "It's impossible to imagine how it could have gone worse," a member of the trial team commented at the end of the first day of her cross-examination. "She was terrible — she complete derailed — gave stuff up — made new stuff up that was a whole new story — different from her grand jury testimony and different from this, and then would just sit there." 97 His thoughts turned to his future closing statement. He planned to ask the jury to do a "thought experiment" by “imagin[ing] that she didn't testify." Setting aside Jessica's testimony altogether, the jury could still return a guilty verdict. Other witnesses' recollections of the same events, he would argue, could lead jurors to conclude beyond a reasonable doubt that the defendant was guilty. And jurors could reach this conclusion themselves. ${ }^{98}$

Prosecutors also considered the potential for jurors to view witnesses' later narratives as corroborating their opening statements. Recognizing the additive value of these contextualizing accounts, one prosecutor viewed them as "a stamp on all the arguments and evidence you've presented" and a means of "buttressing" particular witnesses' credibility. ${ }^{99}$ Another prosecutor noted, in reference to a cooperating witness's testimony, that "it bolsters my credibility when the jury says 'yeah, we heard about that before in the opening." 100 This included the possibility that jurors might notice aspects

\footnotetext{
97 Discussion with trial team, U.S. Att'y's Office, (July 22, 2015), his emphasis.

98 See e.g., Participation in meeting with EM, Ass't U.S. Att'y, (May 5, 2017).

99 Participation in meeting, U.S. Att'y's Office, (June 28, 2015).

${ }^{100}$ Participation in meeting, U.S. Att'y's Office, (June 19, 2015); Participation in meeting, U.S. Att'y's
} 
of opening and closing statements that were inconsistent, leading colleagues to urge trial partners to reconcile their own competing narratives before trial. ${ }^{101}$

2. Mitigating perceptions of the overzealous prosecutor

While discussing opening statements, prosecutors also critiqued behavior that a hypothetical juror might consider overzealous. Though not defined explicitly, prosecutors articulated different indices of this undesirable quality. This included appearing excessively argumentative, confrontational, disrespectful or dismissive when characterizing witnesses or evidence. ${ }^{102}$ Jurors' presence, even in hypothetical form, thus invited prosecutors to share their own common sense understandings of how to distinguish reasonable from excessive advocacy in criminal prosecutions. Returning to the Caprica case that began this article, another exchange illustrated the shifting meaning of this unwanted attribute. In the excerpt below, a prosecutor named David challenged the trial team's decision to have the defendant's mother testify against him in court despite the fact that her name, address, and signature on forged loan applications implicated her in the scheme.

Ken: OK, so you could go through it like that... You're getting the mother to testify?

Office, (Jan. 8, 2015) in which the metaphor of gravy on meat was invoked during a strategy meeting to emphasize the additive quality of corroborating evidence.

${ }^{101}$ See e.g., Participation in meeting with AJ, Ass't U.S. Att'y, (May 5, 2017).

102 See e.g., Participation in meeting with AJ and CZ, Ass't U.S. Att'ys, (May 5, 2017). 
Alex: Yeah, she's going to say that she never signed any documents...

David: Prep the jury for that, so they don't think we're being overzealous...

Ken: You're getting his sister, too?

Alex: Yeah, she's listed on the form as a loan processor.

David: At some point, you should allude to the unpleasant task the defendant has forced the government to do...

Ken: Is there another way to do this? Could you get tax returns... for the mother? ${ }^{103}$

Here, David made his concern about government overzealousness explicit. Despite the legality of calling a defendant's family member as a witness, he explained after the meeting that he found this tactic problematic:

I could understand [this approach] in a murder case- but this is fraud. How is the government going to appear? If I have a father and he's not going to lie on the stand, what good is he? If I have a kid and I won't lie for him, what's the point? ${ }^{104}$

103 Participation in meeting, U.S. Att'y's Office, (Jan. 28, 2014), his emphasis.

${ }^{104}$ Discussion with AM, Ass't U.S. Att'y, (June 18, 2013). 
David's hesitation about bringing the defendant's mother and sister to court reflected his intuition that jurors might share his sense that requiring family members to testify against each other was unfair. ${ }^{105} \mathrm{He}$ thus imputed his common sense idea about just mortgage fraud prosecutions to the trial team's future audience of lay decision-makers. Ken, who found this argument compelling, responded with an alternative approach that helped his colleagues prove the fraudulence of the loan application with tax documents instead.

Prosecutors' sensitivity to jurors' perception of overzealousness also entered discussions of how to characterize cooperating witnesses. On the one hand, cooperators promised to testify truthfully in the hope of receiving lighter sentences in return for their assistance. On the other hand, they engaged in criminal activity themselves - sometimes the same criminal activity as defendants. Though prosecutors did not want to endorse the behavior that brought cooperating witnesses in contact with law enforcement agents, they navigated this fraught relationship with care. In the conversation below, for instance, Maria critiqued her colleague's use of derogatory language to describe cooperating witnesses while acknowledging that her opinion might shift from one case to the next:

Maria: You call the co-conspirators "crooks" and "fraudsters." I'd have a lighter touch on the people who testify. I know you're getting this from my work product...

George: Yeah, this is coming straight from Maria's opening...

\footnotetext{
${ }^{105}$ See also Discussion with DN, Ass't U.S. Att'y, (May 23, 2017) “... [F]amily members against family members is kind of distasteful—you don't want a kid testifying against their parent."
} 
Maria: But in $m y$ case, they weren't testifying, so I had a little more license to dump on them. There's another way to say it — not as pejoratively. 106

As we see here, cooperating witnesses presented a continuing dilemma for prosecutors who sought to differentiate themselves from admitted criminals.

Opening statements that appeared to vouch for, praise, or depict cooperating witnesses as victims were also subject to criticism. This is because one could not predict exactly what such witnesses would say or how truthful their testimony would seem to jurors. In one case, a prosecutor advised a colleague to explain that a cooperator said he didn't know that a transaction was illegal so that the deliverer of the statement did not implicitly vouch for his truthfulness. ${ }^{107}$ In another case, a prosecutor responded to a colleague's comment that a cooperator wanted to start his life with a clean slate and "new beginning" by commenting that "unless you're really confident the jury's going to buy that he turned his life around, I wouldn't vouch for it... You don't know how this guy is going to come across." ${ }^{108}$ In this context, the witness was charged with crimes he committed after signing an agreement with the government - a fact believed to tarnish jurors' opinions of him and undermine their confidence in lawyers who appeared to take him at his word.

In an effort to mitigate a hypothetical juror's perception that they vouched for witnesses, prosecutors encouraged each other to adjust their word choice. One prosecutor, for example, suggested that a colleague use an impersonal construction when characterizing a cooperating witness's testimony by saying "the evidence is going to

\footnotetext{
${ }^{106}$ Participation in meeting, U.S. Att'y's Office, (Jan. 28, 2014), her emphasis.

${ }^{107}$ Participation in meeting, U.S. Att'y's Office, (June 7, 2013), emphasis added.

${ }^{108}$ Participation in meeting, U.S. Att'y's Office, (June 19, 2013).
} 
show" rather than "we're going to provide evidence" to insulate herself from responsibility for his statements. ${ }^{109}$ Another prosecutor addressed this concern by encouraging a colleague to explain that the defendant chose the cooperating witnesses. ${ }^{110}$ If asked to believe the uncorroborated testimony of a witness they disliked, jurors might transfer their distrust or animus to the trial team instead. ${ }^{111}$

Prosecutors also critiqued opening statements that appeared to empathize with witnesses. When an opening statement involved witnesses who were undocumented immigrants, for example, a supervisor objected to a section of a draft that described them as gathering money to pay bribes from their "hard-earned paychecks."112 In light of some Americans' apparent support for President Donald Trump's stance on immigration, he worried that jurors might view undocumented witnesses as earning money at the expense of law-abiding citizens. "I don't know how much we want to make them into victims," he said. ${ }^{113}$

Others more explicitly associated the value of precise language with their roles as "honest brokers" who refrained from "overt argumentation."114 A prosecutor's critique of an opening statement reflected this concern. "When explaining the five transactions you want to be a teacher," he said:

\footnotetext{
${ }^{109}$ See e.g., Participation in meetings, U.S. Att'y's Office, (Jan. 28, 2015; May 5, 2017).

${ }^{110}$ Participation in meeting, U.S. Att'y's Office, (Jan. 7, 2014) during which a prosecutor commented that "the government didn't pick these two, the defendant did when she decided to take kickbacks."

${ }^{111}$ Discussion with DH, Ass't U.S. Att'y, (May 23, 2017).

${ }^{112}$ Participation in meeting, U.S. Att'y's Office, (Feb. 21, 2017).

${ }^{113}$ Participation in meeting with AA, Ass't U.S. Att'y, (Feb. 21, 2017); see also Participation in meeting, U.S. Att'y's Office, (April 17, 2014).

${ }^{114}$ Participation in meeting, U.S. Att'y's Office, (July 9, 2013).
} 
Just talk to them. I know that you enunciate words, but you have to let them flow together and be a regular person. ${ }^{115}$

In this colleague's view, the opening statement's emphatic delivery distanced its author from her lay audience. Another lawyer thought the same opening statement had been "too dramatic" in its opening lines, noting that the story improved as its deliverer "calmed down" and spoke "natural[ly]."116

As a general practice in cases with ambiguous evidence, prosecutors erred on the side of understatement, weighing emphatic claims against jurors' imagined skepticism and defense counsel's imagined counterarguments. In a wire fraud case, for example, a supervisor implored the deliverer of an opening statement not to characterize a defendant's confession as "the most devastating evidence of all."117 Since the defendant did not concede that he lied to the victim or committed wire fraud, the supervisor advised the trial team to proceed with caution: "When I hear confession," he explained, "I'm thinking 'I robbed the bank. I aimed the gun at the bank teller...' That's a confession and this is a little different."118

Language or visual aids perceived to exaggerate or overstate evidence were criticized along similar lines. Discomfort displaying photographs prompted one prosecutor to refer to their inclusion as turning an opening statement into a "dog and pony show"119 and another to comment that if they were going to be used as evidence of physical injuries, photographs should have a "blockbuster" effect that would bowl the

\footnotetext{
115 Participation in meeting, U.S. Att'y's Office, (Jan. 8, 2015).

116 Participation in meeting, U.S. Att'y's Office, (Jan. 8, 2015).

117 Participation in meeting, U.S. Att'y's Office, (April 19, 2017).

${ }^{118}$ Id., his emphasis.

${ }^{119}$ Participation in meeting, U.S. Att'y's Office, (Jan. 28, 2015).
} 
jury over or not be used at all. ${ }^{120}$ To this end, another response to the Caprica opening was illustrative:

I would also be careful about not overcommitting to evidence. You say 60 to 80 percent of mortgages, but you don't know he'll testify to that. I'd say "majority" or something squishier. ${ }^{121}$

This sense of the value of "exact" language was shared by a prosecutor who cautioned the deliverer of another opening statement not to set jurors up to expect something "huge and earth-shattering" that might not be perceived as such. ${ }^{122}$ During the same meeting, a prosecutor advised another colleague not to "bomb-throw" after a peer suggested that "the opening line should be grabbing them [i.e., jurors] by the scruff of their neck."

The creative and imaginative labor that prosecutors devoted to reformulating case stories illuminated their divergent ideas about the relationship between advocacy and professionalism. Though overzealousness - like their broader obligation to seek justice — lacked explicit definition, prosecutors' discussions revealed differing approaches to their case preparation. Reference to hypothetical jurors thus created an opening for prosecutors to bring distinct understandings of their professional responsibilities (however aspirational) to critiques of colleagues' work.

\section{Conclusion}

${ }^{120}$ See e.g., Participation in meetings, U.S. Att'y’s Office, (Oct. 9, 2014; May 5, 2017).

${ }^{121}$ Participation in meeting with DC, Ass't U.S. Att'y, (Jan. 28, 2014); Participation in meetings, U.S. Att'y's Office, (April 3, 2014; April 18, 2014; July 1, 2014; Jan. 8, 2015).

122 Participation in meeting, U.S. Att'y's Office, (Jan. 8, 2015) during which a prosecutor commented that a colleague sounded as though he was welcoming jurors "to the greatest show on earth... when, really, a police officer is going to testify who analyzed all the records"; see also Participation in meeting, U.S. Att'y's Office, (Jan. 7, 2014); Participation in meeting with EL, Ass't U.S. Att'y, (Jan. 8, 2015);

Participation in meeting, U.S. Att'y's Office, (Feb. 21, 2017). 
Reflecting on the role of lay decision-makers during case preparation, a prosecutor explained that "the jury forces us to really think about whether we should do something that we can do in terms of a case." 123 As this article suggests, the "should" of justice does not assume a singular or stable form. Conceptions of the just prosecutorand just prosecution - are subject to continual discussion and reformulation as trial narratives take shape. Through references to jurors' perspectives, prosecutors explain their professional commitments to each other and to themselves. In the process of commenting on evidence and witnesses and developing their authorial voices, prosecutors explicitly and implicitly articulate character traits and values they view as central to their jobs. Part I examined narrative techniques that prosecutors deployed and contested with jurors in mind, including their use of analogies and attentiveness to their role as translators for a lay audience. Focusing on prosecutors' collaborative work in real time, Part II highlighted the substantive and structural implications of prosecutors' concern that jurors might perceive them as incredible or overzealous.

Attention to legal storytelling in real time offers a corrective to studies that treat prosecutors, legal language, or "Law" more generally, as monolithic. The social process by which prosecutors create and revise opening statement narratives brings to light the contingency of their work. This research also offers a window into the vital role of lay knowledge to the exercise of prosecutorial discretion as lawyers scrutinize their professional identities and character through jurors' eyes. In some cases, prosecutors draw on information related to jurors' jobs, families, hobbies, and social affiliations elicited during voir dire. More often, however, prosecutors rely on their own local knowledge to imaginatively and empathically inhabit jurors' roles. In this manner, the

${ }^{123}$ Interview with AM, Ass't U.S. Att'y, (June 18, 2013), his emphasis. 
presence of jurors keys prosecutors' decision-making to lay opinions and interpretations. Ordinary citizens, both real and imagined, are thus tied to the creative and collaborative process of making legal narratives. 